\title{
Reviving the Ganges Water Machine: potential
}

\author{
Upali Ananda Amarasinghe ${ }^{1}$, Lal Muthuwatta ${ }^{1}$, Lagudu Surinaidu ${ }^{2}$, Sumit Anand ${ }^{3}$, and Sharad Kumar Jain ${ }^{4}$ \\ ${ }^{1}$ International Water Management Institute (IWMI), P.O. Box 2075, Colombo, Sri Lanka \\ ${ }^{2}$ Council for Scientific and Industrial Research - National Geophysical Research Institute (CSIR-NGRI), Hyderabad, India \\ ${ }^{3}$ International Water Management Institute (IWMI), ICRISAT Campus, Patancheru, Telangana, India \\ ${ }^{4}$ National Institute of Hydrology, Roorkee, India
}

Correspondence to: Upali Ananda Amarasinghe (u.amarasinghe@ @ cgiar.org)

Received: 17 July 2015 - Published in Hydrol. Earth Syst. Sci. Discuss.: 1 September 2015

Revised: 3 February 2016 - Accepted: 10 February 2016 - Published: 15 March 2016

\begin{abstract}
The Ganges River basin faces severe water challenges related to a mismatch between supply and demand. Although the basin has abundant surface water and groundwater resources, the seasonal monsoon causes a mismatch between supply and demand as well as flooding. Water availability and flood potential is high during the 3-4 months (June-September) of the monsoon season. Yet, the highest demands occur during the 8-9 months (October-May) of the non-monsoon period. Addressing this mismatch, which is likely to increase with increasing demand, requires substantial additional storage for both flood reduction and improvements in water supply. Due to hydrogeological, environmental, and social constraints, expansion of surface storage in the Ganges River basin is problematic. A range of interventions that focus more on the use of subsurface storage (SSS), and on the acceleration of surface-subsurface water exchange, has long been known as the Ganges Water Machine (GWM). The approach of the GWM for providing such SSS is through additional pumping and depleting of the groundwater resources prior to the onset of the monsoon season and recharging the SSS through monsoon surface runoff. An important condition for creating such SSS is the degree of unmet water demand. The paper shows that the potential unmet water demand ranging from 59 to $124 \mathrm{Bm}^{3}$ year ${ }^{-1}$ exists under two different irrigation water use scenarios: (i) to increase irrigation in the Rabi (November-March) and hot weather (AprilMay) seasons in India, and the Aman (July-November) and Boro (December-May) seasons in Bangladesh, to the entire irrigable area, and (ii) to provide irrigation to Rabi and the hot weather season in India and the Aman and Boro seasons in Bangladesh to the entire cropped area. However, the potential for realizing the unmet irrigation demand is high only
\end{abstract}

in 7 sub-basins in the northern and eastern parts, is moderate to low in 11 sub-basins in the middle, and has little or no potential in 4 sub-basins in the western part of the Ganges basin. Overall, a revived GWM plan has the potential to meet $45-84 \mathrm{Bm}^{3}$ year $^{-1}$ of unmet water demand.

\section{Introduction}

Millions of people depend upon the Ganges River. The Ganges River basin, with a land area of more than 1 million hectares (Mha), cuts across four South Asian countries, with India, Nepal, Bangladesh, and China making up 79, 14, 4, and $3 \%$ of the area of the basin. Gangothri Glacier, at an altitude of over 4000 to $7000 \mathrm{~m}$, is the origin of the river, which traverses through steep slopes and enters the plains at an altitude of $300 \mathrm{~m}$ in Haridwar (GoI, 2014). In the plains, it traverses about $2000 \mathrm{~km}$ before its confluence with the Brahmaputra and Meghna rivers in Bangladesh.

Benefits of water permeate the landscape of the Ganges. In its meandering course over $2500 \mathrm{~km}$ from Gangothri Glacier to the Bay of Bengal, fertile land and abundant water resources support both livelihoods and food security of more than 600 million people, of whom the majority live in rural areas (Sharma et al., 2010). River water is an important source for fisheries and other riverine habitats (Payne and Temple 1996), and also for navigation extending a stretch of $1500 \mathrm{~km}$. Hydropower generation with an installed capacity of over 2000 megawatts (MW) is a major financial benefit of the river (GoI, 2014). The Ganges River is also considered sacred and revered by its riparian population, and its water is used for many religious and cultural activities, 
with more than 290 sites set up for tourists to access water along the major rivers and tributaries. Many ecologically sensitive sites, including lakes and wetlands, provide numerous ecosystem services, including maintenance of aquatic organisms for food and medicine, and a space for flood control and nutrient recycling, and maintaining water quality.

Yet, the intense rainfall during the monsoon season and associated floods, combined with extremely low rainfall during the non-monsoon season and associated droughts, cause severe impacts on the large riparian population. Recurrent floods and droughts affect the vulnerable population (the poor, and the women and children) the most (Douglas, 2009). Floods affect millions of people, and damage is caused of hundreds of millions of dollars' worth of property and production annually (e.g., over 7.5 million people were affected and USD 300 million of damage was caused in 2011 alone; CWC, 2013). Water scarcity, both physical and economic in the non-monsoon period due to inadequate water supply or insufficient development, respectively, barely allows cropping to only about 1.3 times the net sown area (GoI, 2014).

Climate change may exacerbate the water-related issues due to extreme variability of rainfall and associated streamflow, although the projections for the Ganges basin are widely divergent. Hosterman et al. (2012) and Immerzeel et al. (2010) projected a decrease in annual rainfall, while Sharmila et al. (2015) and Krishna Kumar et al. (2011) show an increase in monsoon rainfall and longer monsoon seasons. The latter also projected an increase in dry spells during the monsoon, implying that the intensity of precipitation in the rainfall events will increase. However, according to Lutz et al. (2014), water availability in the upstream and also in the low flow periods will increase. While any increase in rainfall, especially in the non-monsoon period, is a good opportunity, any increase in variability of rainfall could be a challenge for water management in the basin. Unless there is adequate storage to buffer the variability, most climate change scenario projections could increase the impacts of floods and droughts substantially on the rapidly expanding population in the basin.

Building surface storage has been the primary response to buffer the variability of streamflow. The reservoirs in the Indian sub-basin have the capacity to store about 48.7 billion cubic meters $\left(\mathrm{Bm}^{3}\right)$. Further surface storage of $7.6 \mathrm{Bm}^{3}$ is planned or under construction (CWC, 2013). When these initiatives are completed, potential surface storage capacity in the Indian sub-basin will be nearly fully developed. Nepal has large surface storage potential that can generate hydropower and augment streamflows during low-flow periods. Yet, less than $1 \%$ of that potential capacity has been developed (FAO, 2014). The hydro-economic analysis of surface storage in the Ganges River by Jeuland et al. (2013) highlighted that, even if much of the storage potential of Nepal is harnessed, there is still only a limited ability to control the peak flows and floods downstream. What will benefit the Ganges River basin is an integrated water resource development plan with an improved groundwater management component, which could change the despair into joy for many millions of inhabitants (Sadoff et al., 2013).

The Ganges Water Machine (GWM), proposed by Revelle and Lakshminarayana (1975), may be the most opportune solution to the severe water challenges in the Ganges River basin. The GWM entails (a) increasing infiltration by spreading flood water over the land area by constructing bunds and increasing seepage from irrigation canals by spreading the canal network, and (b) pumping and depleting groundwater from the aquifers during the pre-monsoon period to create sufficient subsurface storage (SSS) and subsequently recharging the SSS by natural or artificial means during the monsoon period. The GWM envisaged irrigating about 38 Mha of potential cropland and also capturing about $115 \mathrm{Bm}^{3}$ year $^{-1}$ of monsoon runoff for SSS. Over the last 40 years, their estimate of gross irrigated area has already been realized (Amarasinghe et al., 2007). As a result, some areas are experiencing falling groundwater tables (Gleeson et al., 2012), of which at least a part could have been avoided with the GWM. Recurrent floods and droughts batter the basin with increasing frequency. There is already a mismatch between supply demand, and the water challenges are likely to increase with increasing demand. This paper examines the conditions under which the original GWM concept could be revised as a potential solution to the emerging water problems in the Ganges River basin.

This paper proposes the use of SSS as a potential solution to the present-day water storage dilemma, where the flat topography in much of the area, coupled with financial, environmental, social, and international constraints, limits large surface storages in the basin. SSS is now more important than ever before for providing sustainable ecosystem services for livelihoods and benefits. It provides a buffer for rainfall variability. SSS also provides water for irrigation to increase cropped area, and water for use in the domestic and industrial sectors. SSS also eliminates numerous social and environmental costs associated with the development of large surface storage structures. In addition, the regulation of flow through SSS can help alleviate the social impacts of floods and droughts, especially for women and children, who are the hardest hit by such water extremes.

Creation of SSS entails additional pumping of groundwater - out of the aquifers - before the monsoon; this "preparatory" pumping can provide additional water for irrigation and for use in other sectors to enhance the benefits during the non-monsoon months. Provided that subsequent recharge through monsoon rainfall and runoff will replenish the aquifers, the cycle of "pump-deplete-recharge-pump" (PDRP) can ensure sustainability of the enhanced benefits.

The GWM concept is similar to PDRP (Revelle and Lakshminarayana, 1975). The proposal of Chaturvedi and Srivastava (1979) to increase pumping along the perennial and non-perennial tributaries of the Ganges River, and in irrigation canals prior to the onset of the monsoon, resem- 
bles the earlier proposed GWM. However, over the past few decades, population expansion and economic growth has led to tremendous changes in the patterns of land and water use as well as water depletion. Moreover, the basin has several mega urban agglomerates (New Delhi, Dhaka, Kolkata, and Kathmandu), each having large populations of several million people, 18 cities having over 1 million people, and hundreds of cities with over 100000 people. They all have the potential to accelerate economic growth. Thus, there is an urgent need to determine where, and to what extent, additional SSS can alleviate some of these issues.

The following four conditions are necessary to guarantee the success of a PDRP scheme in a given location.

- There must be unmet water demand, which can be used as a reason for depleting a large volume of groundwater via pumping.

- There must be an adequate volume of groundwater available for pumping before the monsoon season.

- There should be adequate monsoon rainfall and runoff to recharge SSS.

- It must be possible to recharge the emptied aquifer using natural surface and subsurface interaction or by artificial methods.

Given the hydrological, socioeconomic, and environmental changes that have occurred in the basin over the last 40 years, and with increasing climate change impacts, the above four conditions are vital for reviving the GWM concept now.

The major objective of this paper is to assess the potential for reviving the GWM in terms of current water use, availability and potential unmet demand at sub-basins in the Ganges. Subsequent studies with detailed surface water and groundwater modeling will be conducted to assess the potential locations, quantities, and the mode of recharge for increasing the PDRP and a sustainable GWM.

Many studies show that a significant unmet water demand already exists within the basin or will emerge in the future. Sapkota et al. (2013) showed that considering environmental flows (EFs) in water management will increase the already unmet demand for other sectors in the upper Ganges River basin. A substantial yield gap also exists in the major cropping system of rice and wheat in the basin (Aggarwal et al., 2000). According to several projections, the irrigated area of the basin will have to be increased by another 10 15 Mha from the present level to meet food and livelihood security in the next 2-3 decades (GoI, 1999; Rosegrant et al., 2002; Molden, 2007). These studies make it very clear that there is substantial unmet demand for consumptive water use (CWU). The exact locations and quantities of unmet demand throughout the basin, however, have not been defined and are the subject of this study.

\section{Water resources of the Ganges River basin}

Of the four riparian countries (Fig. 1), Nepal lies completely inside the basin, India and Bangladesh have 26 and $31 \%$ of their land area in the Ganges basin, and only $0.3 \%$ of the area of China lies within the Ganges.

Table 1 summarizes the overall water resources associated with the four riparian countries. The total renewable water resources (TRWR) of Nepal are estimated as $210 \mathrm{Bm}^{3}$ year $^{-1}$, which includes $198 \mathrm{Bm}^{3}$ year $^{-1}$ internal renewable water resources (IRWR) and $12 \mathrm{Bm}^{3}$ year $^{-1}$ inflow from China. All TRWR of Nepal are inflows to India. This inflow and IRWR surface water and groundwater of $315 \mathrm{Bm}^{3}$ year $^{-1}$ make up the Indian portion of the Ganges TRWR (525 $\left.\mathrm{Bm}^{3} \mathrm{year}^{-1}\right)$, which includes $172 \mathrm{Bm}^{3}$ year $^{-1}$ groundwater from natural recharge.

IRWR from surface water and groundwater resources of the Bangladesh part of the Ganges are estimated as 22 and $5 \mathrm{Bm}^{3}$ year $^{-1}$. Thus, TRWR from surface water and groundwater of the Ganges, from the four riparian countries, are estimated as $552 \mathrm{Bm}^{3}$ year $^{-1}$.

\section{Methodology and data}

Our overall goal is to determine the potential for meeting the unmet water demand through SSS in the Ganges River basin (Fig. 1). We begin with an assessment of the recent water use accounts of the Ganges basin over the period 1998-2011. This analysis follows the water accounting (WA) framework of Molden (1997). The paper then estimates potential unmet irrigation demand of the sub-basins, by considering the irrigated area and water depletion between 2008 and 2011. Finally, the unmet demand is compared with the present level of uncommitted surface water and groundwater resources for assessing the potential sub-basins for PDRP to enhance SSS.

This paper conducts the WA analysis only for the Indian and Bangladesh riparian regions, which contain almost all TRWR, surface storage capacity, and irrigation in the Ganges basin. Hydrologically, the India portion of the Ganges basin has 21 major sub-basins, which are those considered by the Central Water Commission (CWC) of India, the main government agency responsible for water resource development and management in the Ganges River basin. The Yamuna and Son are major rivers draining water to the Ganges from the southern part of the basin. The Ramganga, Ghaghara, Gomti, Gandak, and Kosi are major rivers draining water from the northern regions of the basin. The Bangladesh riparian area includes the Rajshahi, Kulna, Barisal, and parts of Dhaka administrative divisions. 


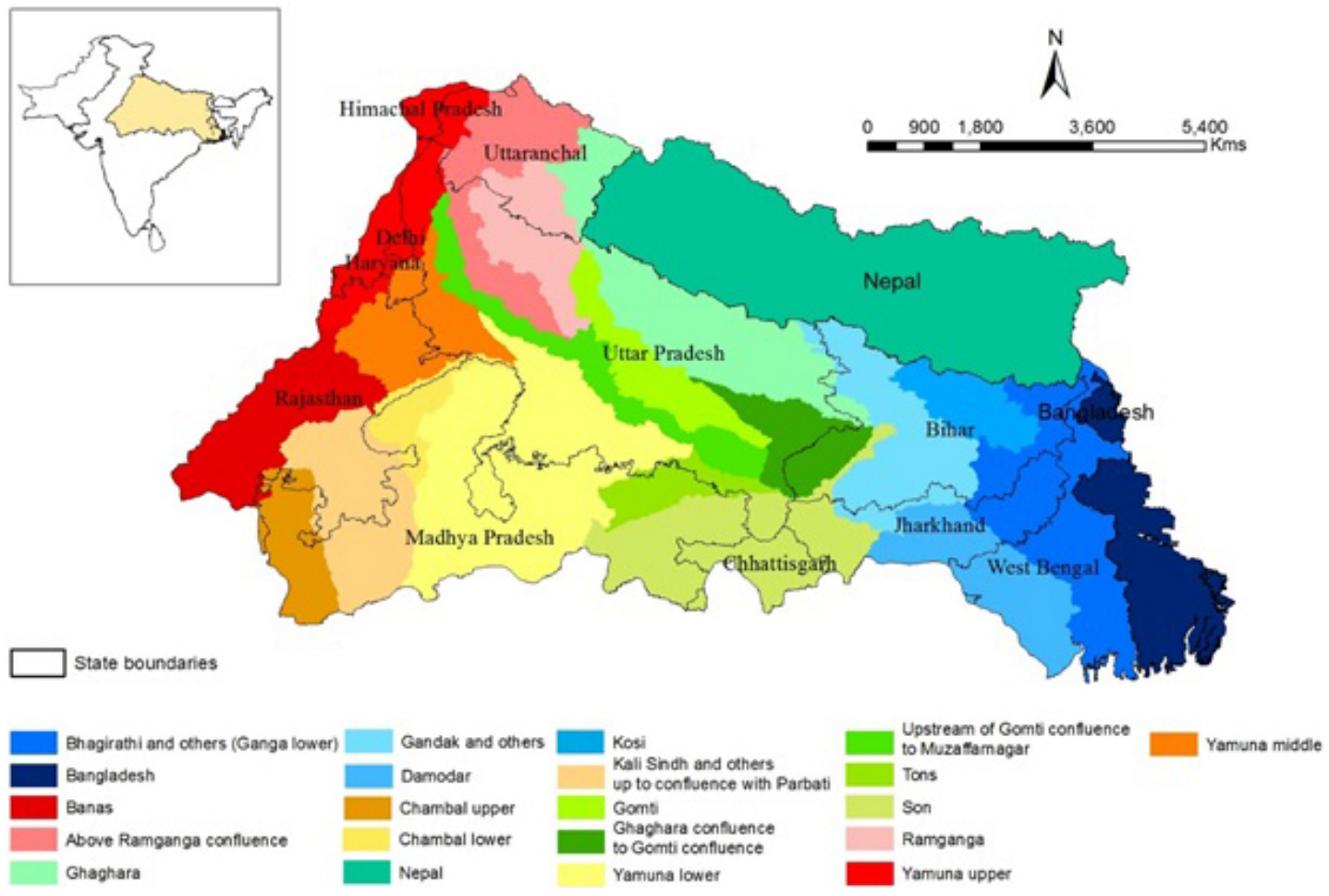

Figure 1. The Ganges River basin and its sub-basins.

Table 1. Water resources of the riparian countries of the Ganges River.

\begin{tabular}{lccccc}
\hline Countries & $\begin{array}{c}\text { IRWR surface water } \\
\left(\mathrm{Bm}^{3} \mathrm{year}^{-1}\right)\end{array}$ & $\begin{array}{c}\text { IRWR groundwater } \\
\left(\mathrm{Bm}^{3} \mathrm{year}^{-1}\right)\end{array}$ & $\begin{array}{c}\text { Inflow from other countries } \\
\left(\mathrm{Bm}^{3} \mathrm{year}^{-1}\right)\end{array}$ & $\begin{array}{c}\text { TRWR } \\
\left(\mathrm{Bm}^{3} \text { year }^{-1}\right)\end{array}$ & $\begin{array}{c}\text { Storage capacity } \\
\left(\mathrm{Bm}^{3}\right)\end{array}$ \\
\hline China & 12 & - & - & 12 & - \\
Nepal & 198 & $20^{\mathrm{a}}$ & $12^{\mathrm{c}}$ & 210 & 0.09 \\
India & 143 & 172 & $210^{\mathrm{d}}$ & 525 & 53.00 \\
Bangladesh & 22 & $5^{\mathrm{b}}$ & $525^{\mathrm{e}}$ & 552 & 0.02 \\
Ganges & $375^{\mathrm{f}}$ & 177 & - & 552 & 53.10 \\
\hline
\end{tabular}

Sources: AQUASTAT database (FAO, 2014); GoI (1999).

Notes: ${ }^{\mathrm{a}}$ all overlap with surface water; ${ }^{\mathrm{b}}$ no overlap with surface water; ${ }^{\mathrm{c}}$ inflow from China to Nepal; ${ }^{\mathrm{d}}$ inflow from Nepal to India; ${ }^{\mathrm{e}}$ inflow from India to Bangladesh; ${ }^{\mathrm{f}}$ includes inflow from China.

WA has three main components.

Depletion: part of the inflow depleted through various processes. Depletion includes the following.

- Process beneficial depletion (evapotranspiration (ET) from the diversions for the intended purposes of producing goods and services)

- Non-process beneficial ET (ET by the processes where diversions are not intended, such as from homesteads, etc.)

- Non-process non-beneficial evaporation (evaporation from water bodies and bare soil surfaces)

- Flows to a sink (a part of the diversions where water quality is deteriorated beyond the use for any pro- ductive purposes or cannot be captured for further use)

Committed outflow: part of the water resources intended to meet environmental water needs and inter-basin diversions.

Uncommitted outflow: part of the inflow that is neither committed nor depleted. It is available for further use.

The largest component of depletion, in general, is the process of ET from irrigation, which is the CWU of crops from irrigation. We estimate the monthly $\mathrm{CWU}$ from irrigation (IRCWU) of 31 different crops or crop groups across districts in the river basins over the period from 1998 to 2011. The total CWU (TCWU) of different crops can be obtained 
from Eq. (1) below using the method discussed in Allen et al. (1998).

The TCWU of a crop in the jth month is

$\mathrm{TCWU}_{j}=\sum_{k=1}^{4} C_{k} \times \mathrm{ETP}_{j} \times d_{j k}$,

where $C_{k}$ is the crop coefficient of the $k$ th growing period, $\mathrm{ETP}_{j}$ is the potential evapotranspiration of the $j$ th month, and $d_{j k}$ is the number of days of the $k$ th growing period in the $i$ th month.

The CWU from rainfall (RFCWU), which is essentially the effective rainfall, is estimated using the United States Department of Agriculture (USDA) Soil Conservation Service method given in Smith (1992). The RFCWU of the $j$ th month is given in Eq. (2):

\section{$\mathrm{RFCWU}_{j}$}

$=\left\{\begin{array}{ll}\left(125-0.2 \times \mathrm{RF}_{j}\right) \times 125 & \text { if } \mathrm{RF}_{j} \leq 250 \mathrm{~mm} \mathrm{month}^{-1} \\ 125+0.1 \times \mathrm{RF}_{j} & \text { if } \mathrm{RF}_{j}>250 \mathrm{mmmonth}^{-1}\end{array}\right.$.

$\mathrm{RF}_{j}$ is the rainfall of the $j$ th month, and IRCWU in the $j$ th month is given in Eq. (3), which is the difference between TCWU and RFCWU of different crops.

$\mathrm{IRCWU}_{j}=\sum_{i \in \text { all crops }} \max \left(\mathrm{TCWU}_{i j}-\mathrm{RFCWU}_{i j}, 0\right)$

Crops and crop groups considered in the analysis include cereals (rice, wheat, jowar, bajra, maize, ragi, barley, and small millets), pulses (gram, arhar/tur and other pulses), oilseeds (groundnut, sesame seed, rapeseed/mustard, linseeds, soybeans, sunflower and other oil crops), potatoes, onions, bananas, and other fruits and vegetables, sugarcane, chili and other spices, cotton, tobacco, fodder, and all other food and non-food crops.

In India, rice takes up a major part of the cropped and irrigated areas in the Kharif season (June-October) (Table 2). Wheat, which is predominantly irrigated, takes up a large part of the cropped area in the Rabi season (NovemberMarch). A small area of rice is irrigated in the summer (hot weather) season from March to May. In Bangladesh, rice is the dominant crop, taking up $87 \%$ of the gross cropped area in the three seasons of Aus (May-August), Aman (JulyNovember), and Boro (December-April). Therefore, rice and wheat dominate the cropping patterns of the basin.

Committed streamflow consists of the EFs and inter-basin water transfers. We use the recommendations of Smakhtin and Anputhas (2006) to assess the annual requirement for EFs. Estimates of EFs correspond to managing the river under six different environmental management classes (EMC). EMC A-F vary from natural (pristine) conditions to slightly, moderately, largely, seriously, and critically modified river conditions. E and F classes are normally considered unacceptable. Although EFs do not influence water management decisions now, we expect them to be under close scrutiny with increasing water abstraction in the basin. Maintaining EFs will be even more prominent in the future, with deteriorating water quality and increasing calls associated with the campaign for a "cleaner Ganga" initiated by the present government (NMCG, 2014).

The average monthly ETP and rainfall (RF) estimates for the districts are obtained from the University of East Anglia, Climatic Research Unit, and the Indian Meteorological Department, respectively. The district-level cropped and irrigated areas are collected from the data published at the website of the Directorate of Economic and Statistics website, Department of Agriculture and Corporation, Ministry of Agriculture (http://lus.dacnet.nic.in/). The crop coefficients, crop growth stages, and cropping calendar are obtained from FAO AQUASTAT database (http://www. fao.org/nr/water/aquastat/water_use_agr/Annex1.pdf), FAO irrigation and Drainage paper 56 (Allen et al., 1998), and from the Agricultural Statistics at a Glance publications by the Directorate of Economic and Statistics, Department of Agriculture India (http://eands.dacnet.nic.in/ PDF/Agricultural-Statistics-At-Glance2014.pdf). The agricultural statistics of Bangladesh districts are collected from various publications of the Year Book of Agricultural Statistics of Bangladesh, published by the Bangladesh Bureau of Statistics (http://www.bbs.gov.bd/PageWebMenuContent. aspx?MenuKey=234).

The estimates of the total cropped and irrigated area and the CWU of the sub-river basins are the aggregate of the estimates obtained for districts. When a district cuts across more than one basin, the estimates of the district are divided according to the geographical area of intersections with subbasins.

\section{Results and discussion}

\subsection{Snapshot of water use accounts: 2009-2011}

Of the TRWR of $552 \mathrm{Bm}^{3}$ year $^{-1}$ (Table 1), the potentially utilizable water resources (PUWR) from surface water and groundwater in India and Bangladesh riparian regions are estimated to be $74 \%$ (or about $408 \mathrm{Bm}^{3}$ year ${ }^{-1}$ ) (Fig. 2, first bar). PUWR includes $266 \mathrm{Bm}^{3}$ year $^{-1}$ of surface water and $142 \mathrm{Bm}^{3}$ year $^{-1}$ of groundwater $(80 \%$ of the natural recharge).

In Fig. 2, the second and third bars summarize the types and sources of depletion associated with CWU. The following is clear from the figure.

- Only $39 \%$ (or about $160 \mathrm{Bm}^{3}$ year $^{-1}$ ) of PUWR was depleted in 2009-11.

- Process CWU accounts for $72 \%$ of the overall depletion, while non-process ET accounts for $22 \%$ and flows to sinks account for $6 \%$ (Fig. 2, second bar). 
Table 2. Cropped and irrigated areas of major crops grown in the basin.

\begin{tabular}{|c|c|c|c|c|}
\hline \multirow[t]{2}{*}{ Crop } & \multicolumn{2}{|c|}{$\begin{array}{l}\text { Cropped area } \\
\left(\text { Mha year }^{-1}\right)\end{array}$} & \multicolumn{2}{|c|}{$\begin{array}{l}\text { Irrigated area } \\
\left(\text { Mha year }^{-1}\right)\end{array}$} \\
\hline & $\begin{array}{c}1998-1999 \\
\text { to } \\
2000-2001\end{array}$ & $\begin{array}{c}2008-2009 \\
\text { to } \\
2010-2011\end{array}$ & $\begin{array}{c}1998-1999 \\
\text { to } \\
2000-2001\end{array}$ & $\begin{array}{c}2008-2009 \\
\text { to } \\
2010-2011\end{array}$ \\
\hline \multicolumn{5}{|l|}{ Indian riparian region } \\
\hline Rice - Kharif & 14.6 & 13.8 & 6.9 & 7.6 \\
\hline Rice - Rabi & 0.5 & 0.3 & 0.4 & 0.3 \\
\hline Rice - summer & 1.4 & 1.3 & 1.5 & 1.5 \\
\hline Wheat - Rabi & 17.2 & 17.4 & 14.9 & 16.0 \\
\hline Maize & 2.7 & 2.5 & 0.7 & 0.6 \\
\hline Other cereals - Kharif & 3.9 & 3.8 & 0.2 & 0.3 \\
\hline Other cereals - Rabi & 0.6 & 0.4 & 0.3 & 0.3 \\
\hline Pulses & 7.5 & 7.1 & 1.6 & 1.8 \\
\hline Oilseeds & 7.8 & 7.3 & 1.8 & 2.4 \\
\hline Vegetables/roots & 2.1 & 2.0 & 1.0 & 1.2 \\
\hline Fruits & 0.6 & 0.5 & 0.2 & 0.2 \\
\hline Sugar & 2.2 & 2.4 & 1.9 & 2.1 \\
\hline Cotton & 0.1 & 0.1 & 0.06 & 0.05 \\
\hline Others & 4.3 & 7.6 & 2.1 & 1.4 \\
\hline \multicolumn{5}{|c|}{ Bangladesh riparian region } \\
\hline Rice - Aus & - & 0.6 & - & 0 \\
\hline Rice - Aman & - & 3.1 & - & 0.5 \\
\hline Rice - Boro & - & 2.4 & - & 2.3 \\
\hline Others & - & 1.3 & - & 1.1 \\
\hline Total & 65.5 & 73.9 & 33.6 & 39.6 \\
\hline
\end{tabular}

Source: estimates based on district-wise data from the Directorate of Economics and Statistics, Department of Agriculture and Cooperation, Ministry of Agriculture, Government of India (GoI), and the Bangladesh Bureau of Statistics.

- Of the process CWU, $75 \%$ and $25 \%$ are from groundwater and surface water, respectively (Fig. 2, second bar).

- Irrigation accounts for $93 \%$, and the domestic and industrial sectors account for 3 and $4 \%$, respectively, of the process CWU (Fig. 2, third bar).

\subsection{Potential for increased water use efficiency and groundwater development}

Figure 2 illustrates that, compared to TRWR, only a small fraction $(27 \%)$ is now lost as process and non-process CWU. Moreover, the process CWU from surface water is only $45 \%$ of the surface storage capacity of the basin, indicating that there is a potential for increasing the water use efficiency of surface water withdrawals in the basin. In addition, only $57 \%$ of the utilizable groundwater resources are currently depleted, indicating substantial potential for increased groundwater development.

It is also possible that some of the water with degraded quality (included in flows to sinks) from one location can become a supply source for downstream locations after mixing with freshwater, provided that freshwater is available for mixing. This is especially important for many stretches of the river in India and downstream of the Farakka Barrage in Bangladesh. These river reaches have low quality or inadequate flows or both during low-flow months for meeting the ecosystem services and requirements for socioeconomic activities (Mirza, 1998; MoEF, 2009; Vass et al., 2010).

Subsurface storage can play a major role in meeting EFs in the low-flow months. Two important elements are missing in the previous annual water accounting procedure. First, annual WA has not considered either the inter-annual and/or intra-annual variability of the supply sources, which are recurrent features in the basin. Second, WA has not considered the minimum requirement for EFs. Ignoring these factors could have major future implications for population expansion, economic growth, and change in lifestyles (Amarasinghe et al., 2007). In addition, all of these factors will be further exacerbated with climate change (Hosterman et al., 2012). The two factors that need to be considered additionally in WA are discussed in brief in the next section. 


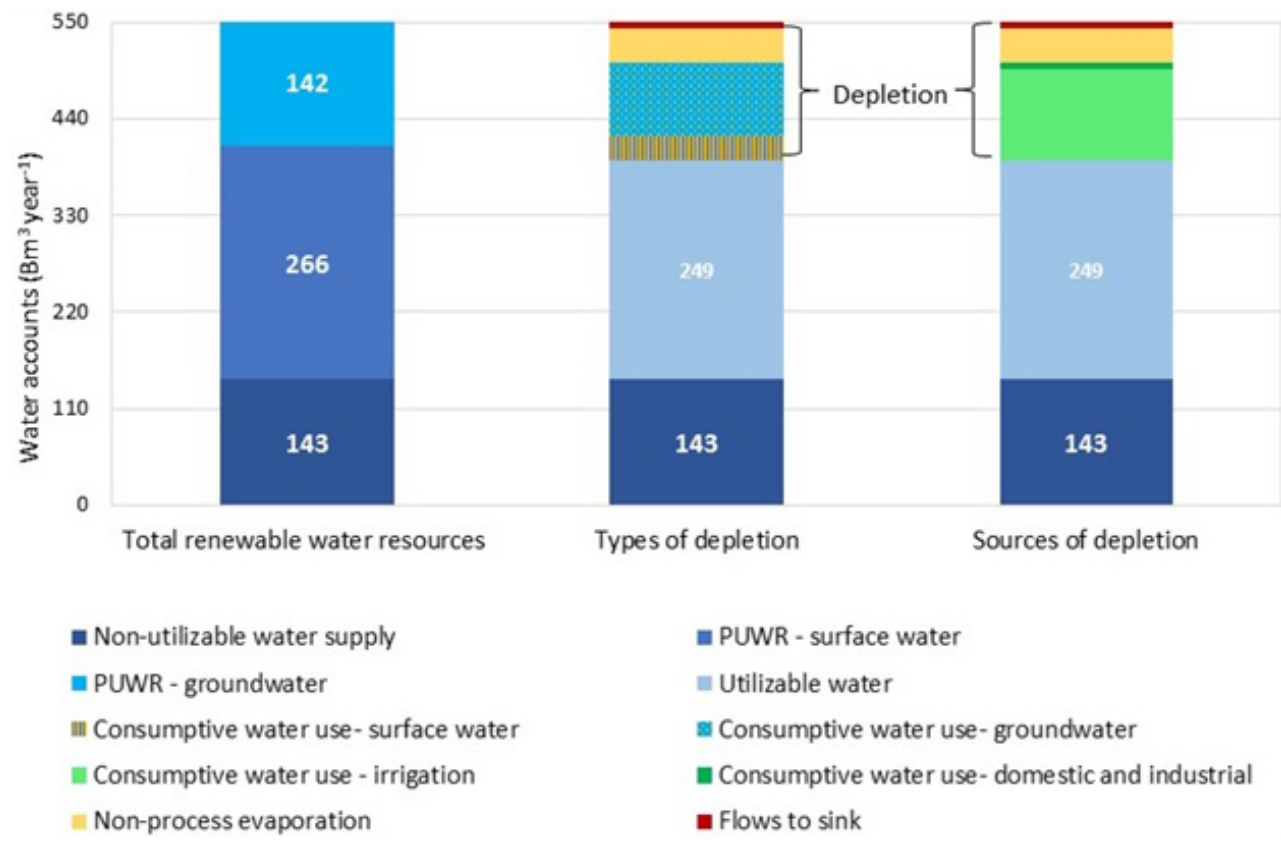

Figure 2. Water use accounts in the Ganges River basin. Sources: utilizable surface water, groundwater and non-utilizable water figures are from the GoI (1999). Other water accounting figures are the authors' estimates.

\subsection{Trends of water supply and use}

The Ganges River basin has a sizable quantity of available runoff after meeting all the demand for CWU (Fig. 3a). This is evidenced by the fact that the average flow at Harding Bridge in Bangladesh (just below the Indian border) was $347 \mathrm{Bm}^{3}$ year $^{-1}$ during $1973-2009$, which is two-thirds of the TRWR of the Indian portion of the basin. From Fig. 3a, we observe the range of dependable streamflows as given below.

- At Harding Bridge, one can expect a discharge of at least $304 \mathrm{Bm}^{3}$ year ${ }^{-1} 75 \%$ of the time, or in at least 3 of 4 years.

- In an extreme flood year with an average recurrence interval of 10 years, the flow is $436 \mathrm{Bm}^{3}$ year $^{-1}$.

- In an extreme drought with an average return period of 10 years, the flow is $271 \mathrm{Bm}^{3}$ year $^{-1}$.

Figure 3a illustrates that a sizable quantity of water flows to the sea, even in an extreme drought year. However, annual aggregate flows illustrated in Fig. 3a hide the extremely low flows in the non-monsoon months. The total flow between January and May is only approximately $27 \mathrm{Bm}^{3}$ or $4 \%$ of the average annual runoff (Fig. 3b). Groundwater as base flow contributes much of the low flows, which will not be adequate for meeting the increasing CWU demand of all the sectors while maintaining adequate environmental flows. The SSS replenished through monsoon runoff can only increase the dry season environmental flows.
Between 2009 and 2011, the three major sectors (agriculture, domestic, and industry) depleted about $150 \mathrm{Bm}^{3}$ year $^{-1}$ as process and non-process CWU (Fig. 4). Groundwater contributes a major portion of the process CWU. The dependence on groundwater, which has increased by $27 \%$ over the last decade, is most prominent in water-stressed years.

The future demand for water in the basin will rapidly increase in the coming decades. Amarasinghe et al. (2007, 2014) showed that, under the business-as-usual scenario, CWU demand from surface water will more than double by 2025 , while groundwater demands will increase by $60 \%$. Given the variability of the flow, and the increasing attention for EFs, meeting even a fraction of the additional CWU demand will be a serious challenge in the future.

Aggregate annual figures also hide large intra-annual variation of irrigation CWU (Fig. 5). The process CWU is highest in the Kharif season (wet season), but rainfall meets a major portion of that demand. Irrigation, which is a critical need for the rest of the year, accounts for $75 \%$ of total process CWU between November and May; this is about $85 \mathrm{Bm}^{3}$ of CWU (64 and $21 \mathrm{Bm}^{3}$ from groundwater and surface water, respectively), compared to an average flow of $44 \mathrm{Bm}^{3}$ in the river during this period.

January to May is the most critical period for meeting any additional water demand in the basin. During this period, the flow of the river is only about $27 \mathrm{Bm}^{3}$. However, the additional demand projected in the future could be much higher. For example, another $85 \mathrm{Bm}^{3}$ would be needed by 2050 to meet the irrigation CWU alone in the India and Bangladesh riparian regions. If past water use patterns are an indicator of 

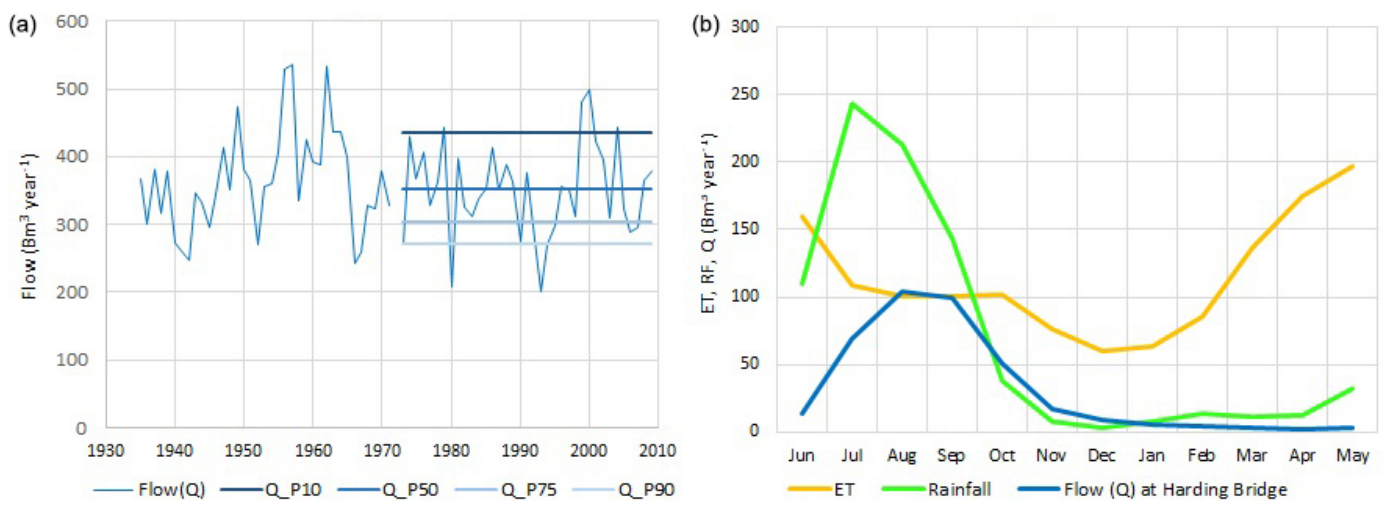

Figure 3. (a) River flow $(Q)$ at Harding Bridge, and (b) average monthly ET, rainfall (RF), and river flow $(Q)$ at Harding Bridge between 1998 and 2008. Sources: rainfall (Indian Meteorological Department), ET (University of East Anglia, Climatic Research Unit, Norwich, UK, 2014), and river flow (Institute of Water Modelling, Dhaka, Bangladesh).

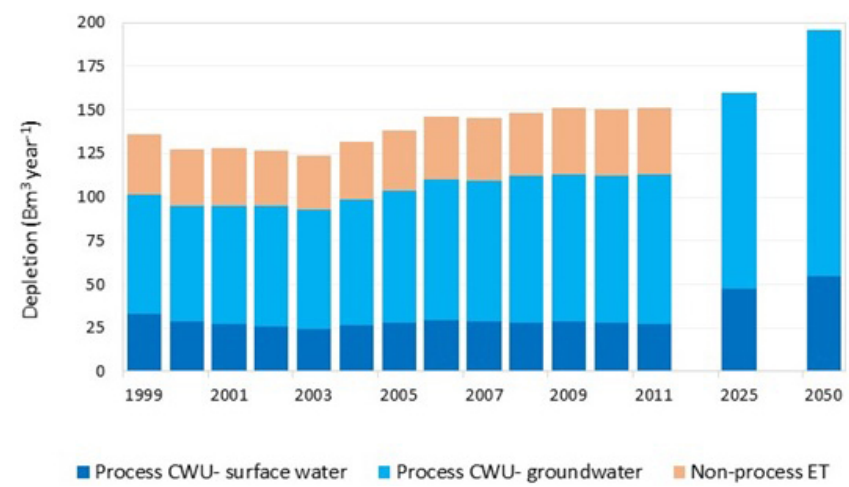

Figure 4. Water use in the Ganges River basin - past trends and projections. Source: trends (1999-2011) are the authors' estimates. The CWU projections are based on Amarasinghe et al. (2007, 2014).

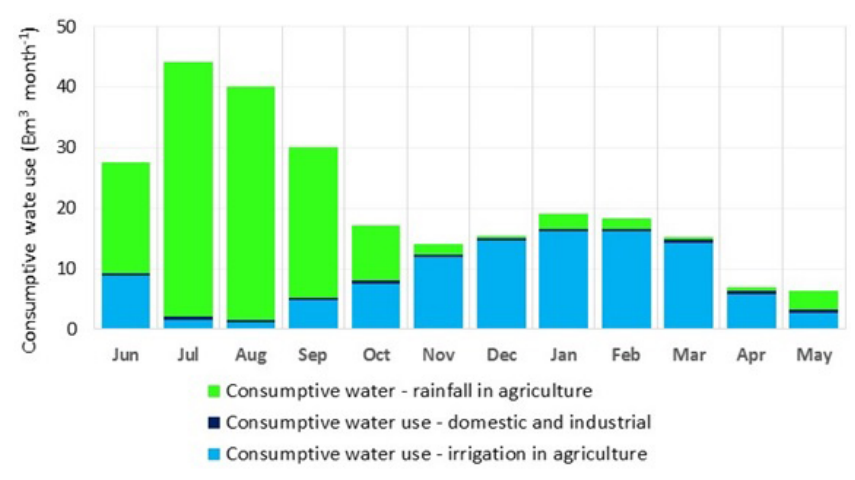

Figure 5. Average monthly CWU between 1999 and 2011.

future use, much of this additional demand will occur in the non-monsoon period, and that also mostly from groundwater irrigation.

The projections made by Amarasinghe et al. (2007) are conservative, at best. The projection of gross irrigated area by the GoI, a commonly used estimate for policy planning, is set to more than double by 2050 (GoI, 1999), which is another $50 \%$ more than that projected by Amarasinghe et al. (2007). If this is going to be a reality, there could be another 20$30 \mathrm{Bm}^{3}$ of additional CWU demand in India during the nonmonsoon months.

\subsection{Environmental flows}

EFs are an integral portion of the committed flows in water accounts. However, water allocation for EFs has low priority and is not considered in current basin water management plans. The water demand projections of the GoI allocated only $20 \mathrm{Bm}^{3}$ of the mean annual runoff for EFs in 2050 (GoI, 1999), which is even less than the total flows in the nonmonsoon period. However, EF estimates of Smakhtin and Anputhas (2006), based only on the hydrological variability of the basin, are significantly higher than the GoI estimate, and vary from 68 to $12 \%$ of the mean annual runoff. The EMC A (natural - pristine - condition) requires the highest EFs, while EMC F (critically modified condition) required the lowest.

Figure 6 shows the estimates of EFs based on the method by Smakhtin and Anputhas (2006) for managing the river at the level of EMCs A-F. The lowest EF estimate for EMC F, shown by the bottommost blue cross section (dark blue), is equal to $63 \mathrm{Bm}^{3}$ year $^{-1}$. The cumulative totals of the subsequent blue cross sections show EF estimates for EMCs E-A; i.e., the EF estimate for EMC E is 79 (= $63+16) \mathrm{Bm}^{3}$ year $^{-1}$; EMC D is $105(=79+26) \mathrm{Bm}^{3}$ year $^{-1}$; EMC C is $152(=105+47) \mathrm{Bm}^{3}$ year $^{-1}$; EMC B is 231 $(=152+79) \mathrm{Bm}^{3}$ year $^{-1}$; and EMC A is $357(=231+$ 126) $\mathrm{Bm}^{3}$ year $^{-1}$.

The two line graphs in Fig. 6 show the sum of CWU and the actual annual river flows (solid line), and the sum of CWU and $Q \_$P75 river flows (dashed line). It shows that the average uncommitted flows of the river, at present, are barely adequate to meet the annual EF requirement of EMC A. And 


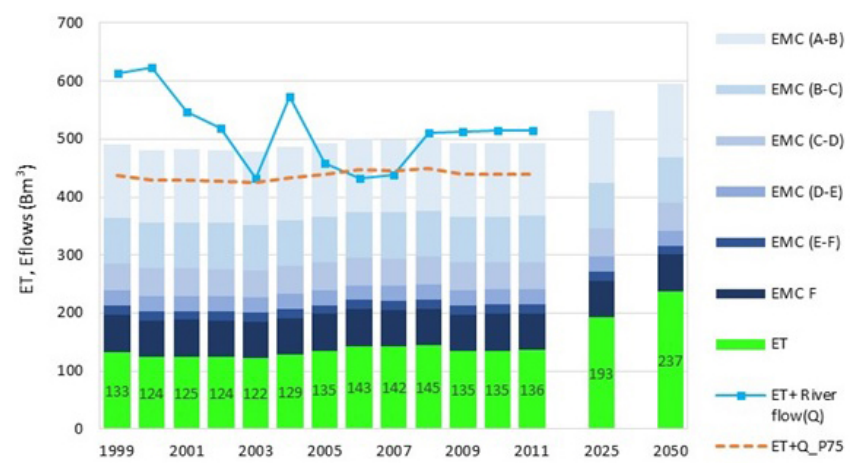

Figure 6. ET and EF estimates for different environmental management classes (EMCs).

in every 1 out of 4 years, the river is under extreme pressure to maintain the EFs of EMC B. This situation can only be exacerbated in the future with increasing demand and deterioration of water quality. By 2050, total ET (process CWU and non-process ET) is projected to be over $235 \mathrm{Bm}^{3}$ year $^{-1}$. In such an eventuality, the river flow will often be less than the EFs for EMC B.

Although this analysis does not show EF requirements during the low-flow period, it is clear that EFs are critical for maintaining the health of the river during such periods. Also, importantly, it is during these periods when present river flows are inadequate to meet this EF demand. Moreover, EMCs $\mathrm{E}$ and $\mathrm{F}$ are generally unacceptable for managing EFs, and EMCs A and B are realistically not possible to maintain with the present level of development. The present average runoff of more than $340 \mathrm{Bm}^{3}$ year $^{-1}$ is adequate to meet the EF of EMC C of $152 \mathrm{Bm}^{3} \mathrm{year}^{-1}$, and the additional process CWU water demand of about $85 \mathrm{Bm}^{3}$ year $^{-1}$ projected for 2050.

Regardless of the magnitude of EF estimates and CWU projections, it is clear that irrigation will account for a major part of the additional water depletion in the basin. Furthermore, much of this additional CWU demand will be required during low-flow periods. With the recent attention given to the "cleaner Ganga" campaign, more flows are also required in the river during this period. Thus, additional storage, whether surface or underground, is critical for meeting the future water requirements of the basin. However, due to social and environmental constraints for additional surface storage, the potential solution to augment water supply during the low-flow period is additional SSS.

In fact, strict maintenance of EF, and also the return flows of additional irrigation from the SSS, can increase the dryseason river flows, especially in the downstream region of the basin. Thus, the additional SSS has the potential to benefit the downstream region of the basin, such as the Bangladesh riparian region, by way of both mitigating floods in the monsoon period and increasing water supply in the dry period.

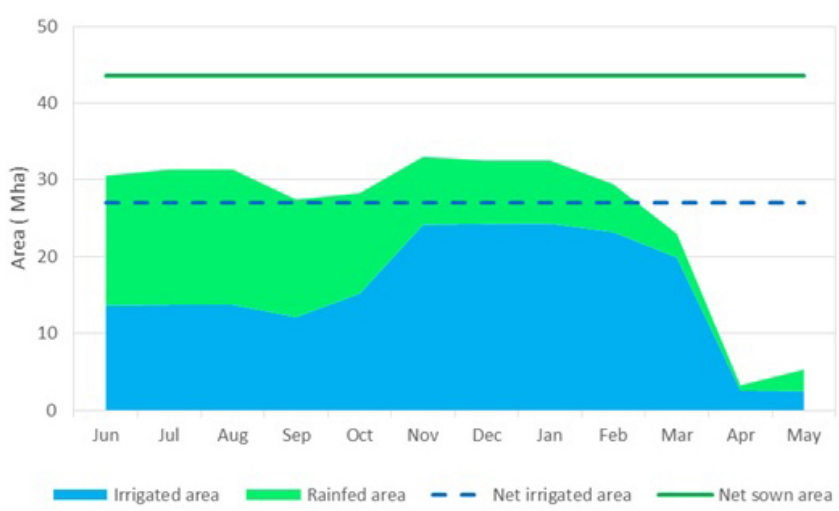

Figure 7. Monthly actual and net irrigated and cropped areas in the Ganges River basin (2008-2011).

\section{Potential unmet CWU demand of sub-basins}

The only feasible strategy for creating additional SSS is via additional pumping and depletion (ET) of groundwater before the monsoon season. According to land and water use patterns, there is a potential for preparatory pumping in the Rabi and summer (hot weather) seasons. This can be illustrated by the irrigated and cropped areas (Fig. 7) and monthly CWU (Fig. 5).

In the Kharif season of the Indian riparian region, the irrigated area is low (only $43 \%$ of the cropped area), and irrigation CWU is even lower (only $16 \%$ of the total CWU) due to monsoon rains. In contrast, the irrigated area is $75 \%$ of the total cropped area, and irrigation CWU is $94 \%$ of the total CWU in the Rabi season. In the Bangladesh riparian region, very little irrigation is required in the Aus and Aman seasons (about $20 \mathrm{~mm}$ ), whereas the irrigation CWU is substantially higher in the Boro season (about $383 \mathrm{~mm}$ ). This shows that the additional irrigated area in the Rabi and Boro seasons in India and Bangladesh, respectively, can result in a proportionally larger irrigation CWU. If groundwater meets this additional irrigation CWU, it can create additional SSS. The months of April and May have relatively higher CWU. Therefore, any additional irrigation during these 2 months requires even higher irrigation $\mathrm{CWU}$, and hence has the potential to create higher SSS.

We consider two scenarios to assess the potential for SSS that can be created with preparatory pumping at the sub-basin level in the Ganges River basin.

- Scenario 1 assesses the potential for increasing gross irrigated area in the Rabi and hot weather seasons in the Indian region, and Aman and Boro in the Bangladesh riparian region. Here, groundwater pumping will be increased only to bridge the gap between actual irrigated area and the irrigable area, i.e., the net irrigated area.

- Scenario 2 assesses the potential for increasing the gross cropped area in the Rabi and hot weather seasons in the 
Indian region and the Boro and Aman seasons in the Bangladesh regions. Here, groundwater pumping will be increased to bridge the gap between actual irrigated area and the actual cropped area.

The highest potential for expanding irrigated area exists in the lower Yamuna sub-basin, where the maximum irrigated and cropped areas of 3.64 and 6.19 Mha, respectively, are achieved in the Rabi season. Hardly any area is cropped or irrigated in April and May. Therefore, the following is possible in the lower Yamuna sub-basin.

- Under Scenario 1, it is possible to irrigate another 0.22 Mha in the Rabi season and close to 3.82 Mha in the hot weather season (Table 3, columns C8 and C9). Therefore, the additional irrigable area of 4.04 Mha could account for $7.8 \mathrm{Bm}^{3}$ year $^{-1}$ of groundwater CWU (Table 4, column C1).

- Under Scenario 2, it is possible to irrigate another 2.55 Mha in the Rabi season and 6.15 Mha in the hot weather season (Table 3, columns C10 and C11). This additional area could account for another 18.7 $\mathrm{Bm}^{3}$ year $^{-1}$ of groundwater CWU (Table 4, column C2).

In the Bhagirathi sub-basin, the maximum cropped and irrigated areas are achieved in the Kharif season. The irrigated area in the Rabi season is less than one-third of the irrigated area and only $10 \%$ of the cropped area in the Kharif season. So, there is potential for increasing irrigation in the Rabi season. Similar potential exists for such an increase between April and May. This has the potential to increase 4.615.1 $\mathrm{Bm}^{3}$ year $^{-1}$ of groundwater irrigation CWU.

Similarly, the Ramganga sub-basin in the upstream has the potential to increase $2.5-3.2 \mathrm{Bm}^{3}$ year $^{-1}$ of CWU through additional groundwater irrigation. However, unlike the lower Yamuna and Bhagirathi sub-basins, much of this potential exists only through irrigation between April and May.

The Bangladesh riparian region in the downstream of the Ganges has a similar situation to that of Ramganga. Although this region has a high groundwater irrigated area and CWU, it has the potential to increase irrigated area by 1.7-4.4 Mha. Much of this potential increase in area is in the Aman season (Table 3). However, due to the higher irrigation requirement, much of the potential increase in irrigation CWU is in the Boro season. Overall, this region has the potential to increase irrigation CWU by up to $4.8 \mathrm{Bm}^{3}$ year $^{-1}$.

Table 4 shows that all sub-basins in the Ganges River basin have the potential to increase irrigation CWU between 59 and $124 \mathrm{Bm}^{3}$ year $^{-1}$ of groundwater under scenarios 1 and 2 , respectively. However, realization of this full potential is difficult given the current water use and availability in different sub-basins. Figure 8a shows the present level of groundwater exploitation (groundwater CWU as a percentage of groundwater resources), and Fig. $8 \mathrm{~b}$ indicates the potential for increasing process CWU to create SSS in the sub-basin.

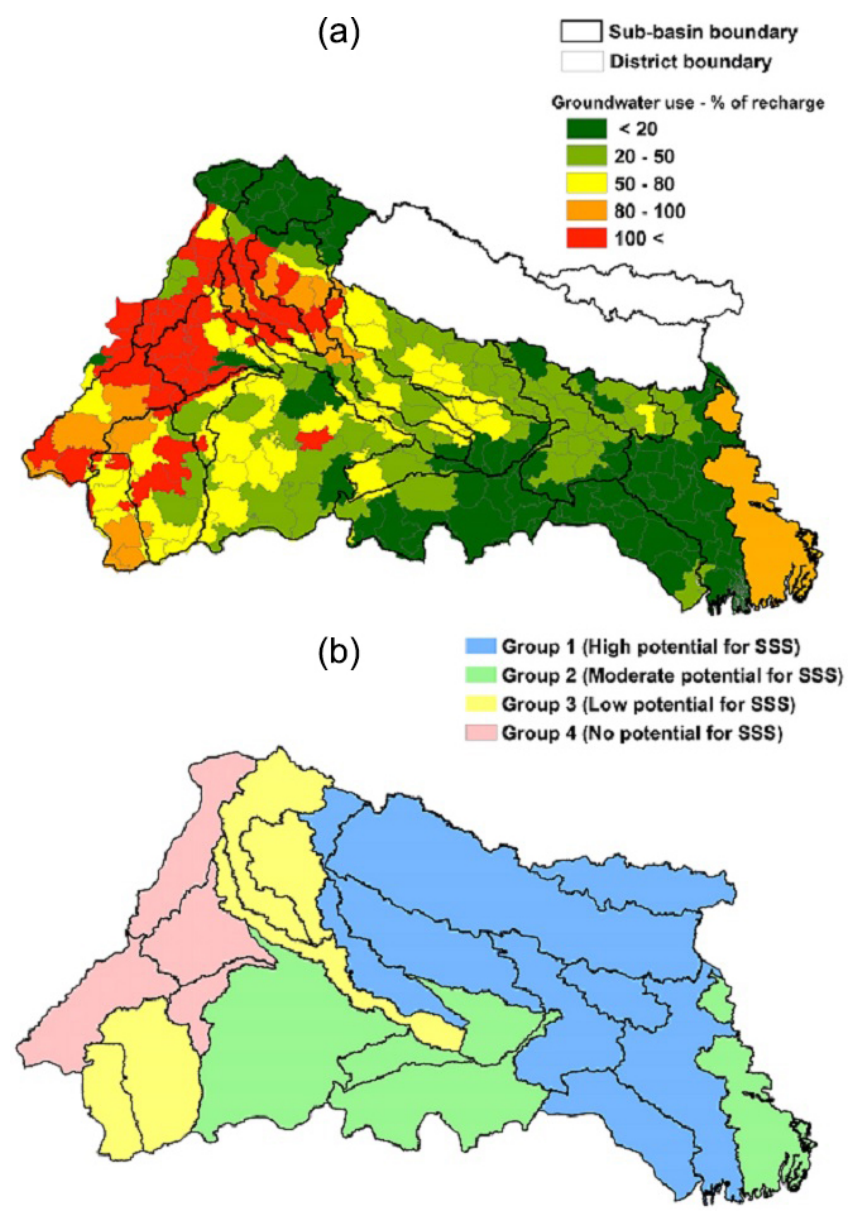

Figure 8. (a) Groundwater exploitation at present. (b) The potential for increasing SSS in the Ganges basin.

The middle and upper Yamuna basins have already exhausted their total water resources (Fig. 8a), where even the process CWU values are 101 and $97 \%$ of the total water resources, respectively (Table 4). Any further increase in process CWU would only exacerbate the unsustainable water use. The middle and upper Yamuna sub-basins have no potential for PDRP and increasing SSS. The Banas and lower Chambal also have high CWU relative to their total water resources, and the potential increases in process CWU would be significantly higher than their available water resources. These four sub-basins have very little or no potential for PDRP and increasing SSS (Fig. 4b, red color).

The sub-basins: above the Ramganga confluence, Ramganga, upper Chambal, Kali Sindh, and the upstream of the Gomti confluence and the Bangladesh riparian region have substantially high groundwater use. These sub-basins have very few uncommitted groundwater resources for further increase in groundwater CWU. Any further increase in groundwater CWU even under Scenario 1 is possible only with substantial recharge of the aquifers during the monsoon period. 


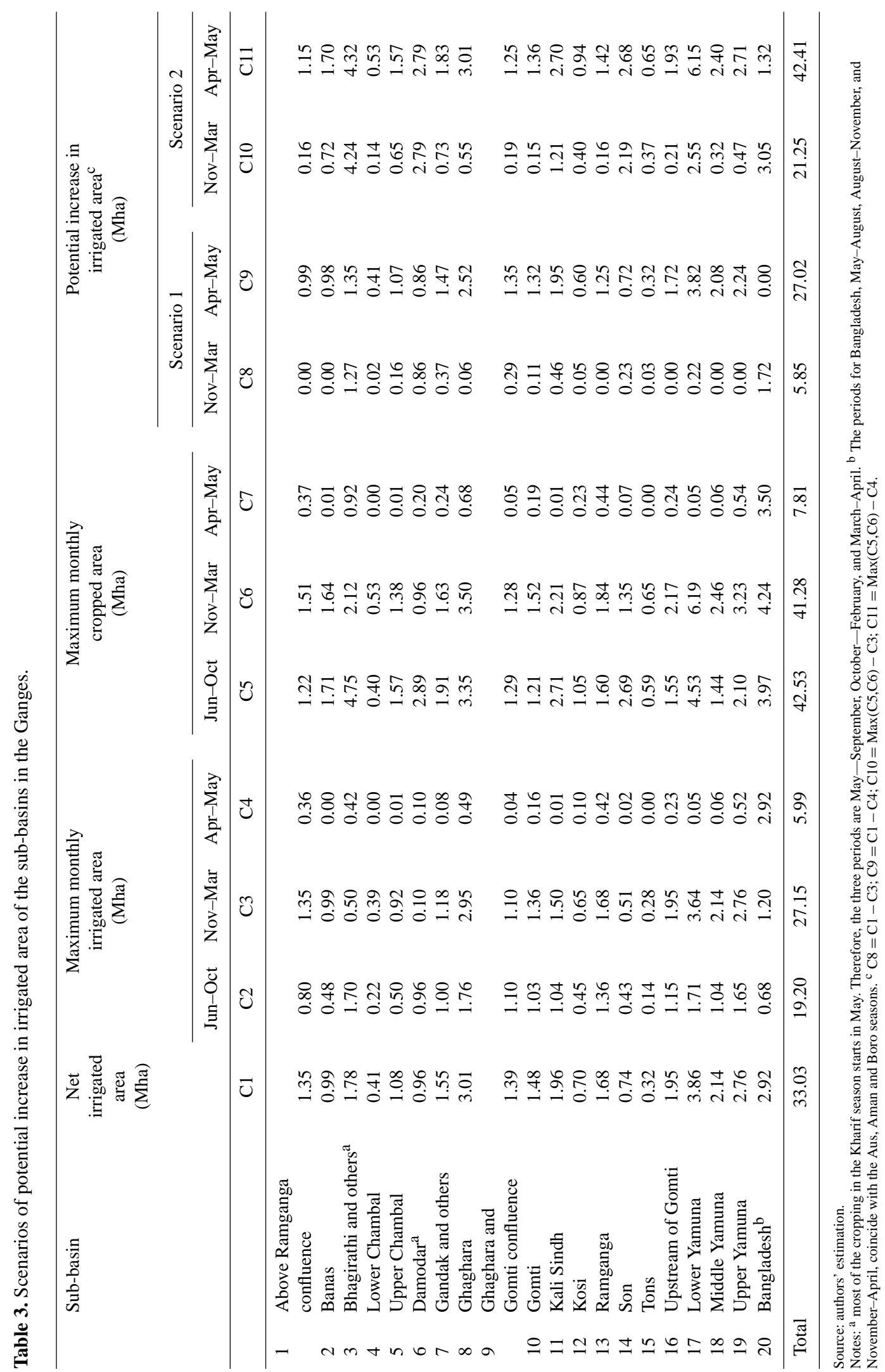




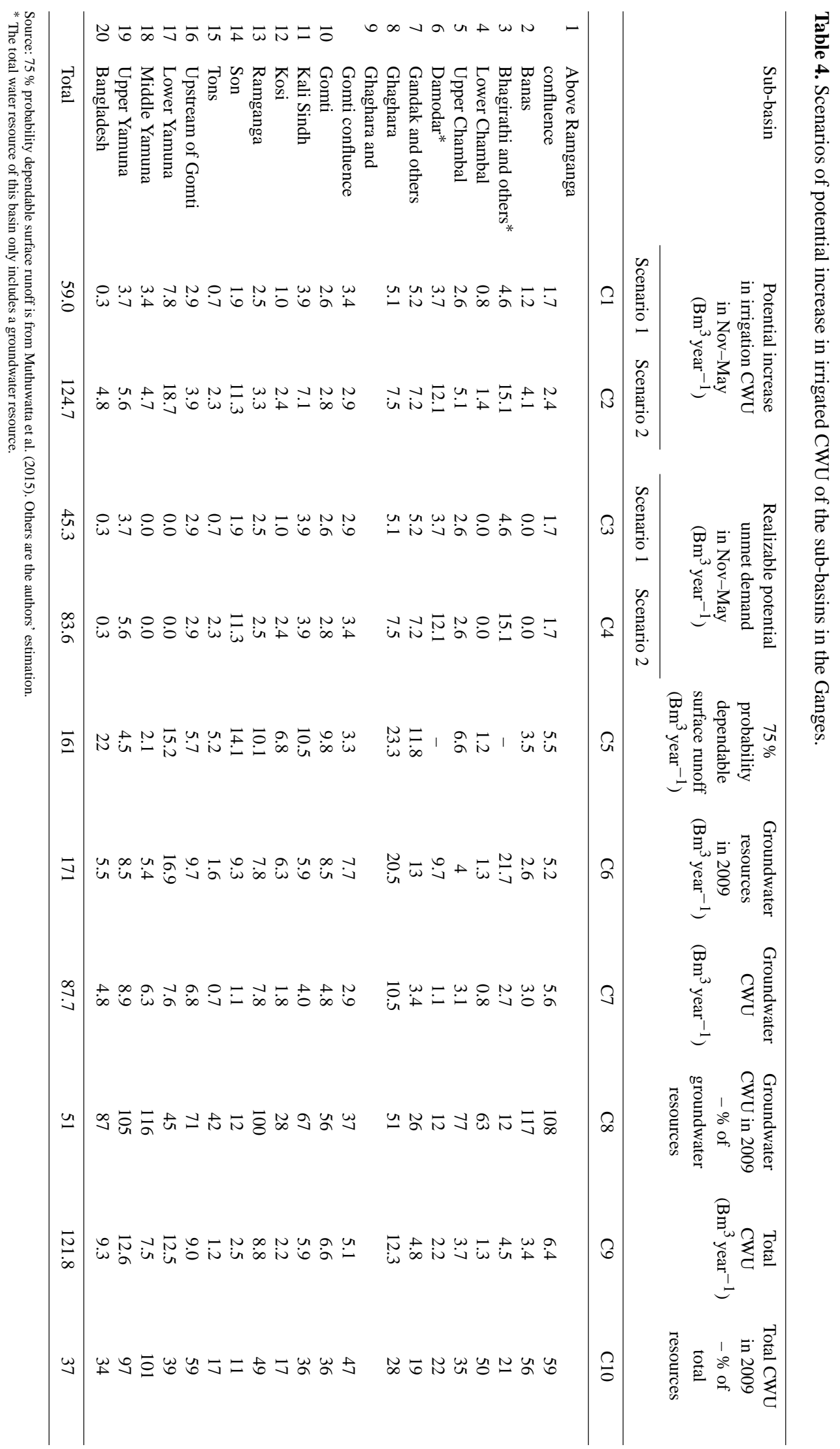


These sub-basins have low potential for PDRP and creating SSS (Fig. 4b, yellow color).

The lower Yamuna, Son, and Ghaghara, between the Ghaghara and Gomti confluence, and Tons sub-basins have sufficient uncommitted groundwater resources to meet the increased CWU under Scenario 1 (Table 4), but are not sufficient under Scenario 2. However, the uncommitted total water resources in these basins can meet the increased irrigation CWU under both scenarios. The potential for increasing groundwater CWU under Scenario 2 depends on the ability of managed aquifer recharge programs to capture the uncommitted monsoon surface runoff. These basins have a moderate potential for PDRP and increasing SSS (Fig. 4b, green color).

In the other sub-basins, the present levels of groundwater development are very low. They have sufficient uncommitted groundwater resources to meet the increased irrigation CWU under both scenarios. In these basins, natural interactions between groundwater and surface water can recharge the SSS created by the depletion of groundwater resources. These basins have the highest potential for PDRP and increasing SSS (Fig. 4b, blue color). Although we have not considered Nepal for this analysis, given their vast water resources and very low irrigation CWU at present (FAO, 2014), it is a natural candidate for a high potential category.

Given the constraints of water surface and groundwater availability and high water use at present in the four groups, only $45-84 \mathrm{Bm}^{3}$ year $^{-1}$ can be potentially realizable as SSS for meeting the unmet demand under the two scenarios. Whether such quantities can actually be depleted on an annual basis depends on many other hydrologic factors, which include the following.

- Feasibility and sustainability of additional groundwater pumping without creating environmental dis-benefits

- Magnitude of the current monsoon runoff in sub-basins, which is available for recharging SSS.

- The ability to recharge SSS through monsoon runoff, especially during 3-4 months of the monsoon season, using natural or artificial interaction of surface water and groundwater. This recharge is essential for sustainable groundwater use.

Detailed surface water and groundwater modeling studies would be needed to assess these concerns. Other factors that may determine the potential benefits of SSS include the following.

- Properties of the soil, and the "crop holidays" (i.e., a temporary fallow period when the cultivation of a particular crop does not take place) required for the soil in between intensive cropping in the Rabi and Kharif seasons

- People's willingness to increase cropping and irrigation intensities to $300 \%$
- Access to energy for additional pumping

- Economic assessment of optimal re-allocation of water under various SSS strategies

These require agronomic feasibility studies, reduction of the dependency on electricity for pumping, feasibility of using alternative energy sources such as solar, and analysis of the social and economic costs, benefits, and tradeoffs of various surface and subsurface storage plans.

\section{Conclusions}

A potential solution to Ganges water problems is to create additional SSS by means of reviving the GWM. One of the necessary conditions for reviving the GWM is ensuring there is unmet water demand. This analysis finds that between 59 and $124 \mathrm{Bm}^{3}$ year $^{-1}$ of unmet demand exists beyond the current water use under two different irrigation water use scenarios. The first scenario increases the gross irrigated area in the Rabi and hot weather seasons. The second scenario increases the gross cropped area in the Rabi and hot weather seasons.

However, given the current water use and availability patterns, all that potential cannot actually be realized in most sub-basins of the Ganges. While some basins (Gandak, Ghaghara, Gomti, Kosi, Bhagirathi, Damodar, and Nepal) have adequate groundwater resources to fully realize the irrigation potential, some other basins (middle Yamuna, upper Yamuna, Banas, and lower Chambal) have little or no water resources to realize the estimated irrigation potential. A few sub-basins (above the Ramganga confluence, Ramganga, upper Chambal, Kali Sindh, and upstream of the Gomti confluence and the Bangladesh riparian region) have low potential, and others (lower Yamuna, Son, Ghaghara, between the Ghaghara and Gomti confluence, and Tons) have moderate potential for increasing the irrigation PDRP and creating SSS. Overall, it is feasible to realize between 45 and $84 \mathrm{Bm}^{3}$ year $^{-1}$ of SSS to meet the potential unmet demand.

One of the most challenging aspects of reviving the GWM is to maintain the required flows during the low-flow period. Because EF is not part of the current water management plans, many stretches of the river already have an unacceptable level of low flows in the dry season. This may require substantial changes to water releases from the reservoirs upstream and re-allocation of canal irrigation in the dry season, when irrigation demand is the highest. Given the limited potential of surface storage in the basin, augmenting SSS is the best potential option for re-allocating canal water and also for increasing base flows during the non-monsoon period.

However, where and to what extent the SSS can be created through PDRP without affecting the dry-season flows in the downstream riparian regions require further hydrogeological, socio-economic and institutional analyses. Being a transboundary river, it is important to assess ways of strict 
maintenance of dry-season $\mathrm{EF}$ and other water requirements of the downstream riparian region, especially Bangladesh. Such analysis, which is beyond the scope of this paper, requires the knowledge of surface runoff of a smaller watershed, the extent and spatial distribution of groundwater avail- ability and depletion, EF during the dry periods, the capacity to recharge through natural or artificial means during short periods of wet spells in the monsoon, and the socio-economic cost and benefits and tradeoff. 


\section{Appendix A: Acronyms}

$\begin{array}{ll}\text { CWC } & \text { Central Water Commission } \\ \text { CWU } & \text { Consumptive water use } \\ \text { EMC } & \text { Environmental management class } \\ \text { ET } & \text { Evapotranspiration } \\ \text { GoI } & \text { Government of India } \\ \text { GWM } & \text { Ganges Water Machine } \\ \text { IRCWU } & \text { Consumptive water use from irrigation } \\ \text { IRWR } & \text { Internal renewable water resources } \\ \text { PDRP } & \text { Pump-deplete-recharge-pump } \\ \text { PUWR } & \text { Potentially utilizable water resources } \\ \text { RFCWU } & \text { Consumptive water use from rainfall } \\ \text { SSS } & \text { Subsurface storage } \\ \text { TCWU } & \text { Total consumptive water use } \\ \text { TRWR } & \text { Total renewable water resources } \\ \text { WA } & \text { Water accounting }\end{array}$


Author contributions. Upali A. Amarasinghe and Lal Mutuwatte are fully responsible for the analysis and writing of this paper. Lagudu Surinaidu and Sharad Kumar Jain have provided data and comments and suggestions during the analysis and write-up. Sumit Anand assisted in collecting data and generating GIS maps.

Acknowledgements. This research study was undertaken as part of the CGIAR Research Program on Water, Land and Ecosystems (WLE) by the International Water Management Institute (IWMI), Colombo, Sri Lanka, and the National Institute of Hydrology (NIH), Roorkee, India. The authors appreciate the useful comments provided by an anonymous reviewer and Vladimir Smakhtin, team leader and principal researcher of IWMI, on an earlier draft of this paper. The authors also thank the two anonymous reviewers and Pieter van de Zaag for providing very useful and constructive comments during the review process.

Edited by: P. van der Zaag

\section{References}

Aggarwal, P. K., Talukdar, K. K., and Mall, R. K.: Potential yields of rice-wheat system in the Indo-Gangetic plains of India, New Delhi India: Rice-Wheat Consortium for the Indo-Gangetic Plains, Paper Series, 10, 12 pp., 2000.

Allen, R. G., Pereira, L. S., Raes, D., and Smith, M.: Crop evapotranspiration - Guidelines for computing crop water requirements, FAO, Rome, FAO Irrigation and Drainage Paper 56, 300 pp., 1998.

Amarasinghe, U. A., Shah, T., Turral, H., and Anand, B. K.: India's water future to 2025-2050: business-as-usual scenario and deviations, IWMI Research Report 123, International Water Management Institute (IWMI), Colombo, Sri Lanka, 47 pp., 2007.

Amarasinghe, U. A., Sharma, B. R., Muthuwatta, L., and Khan, Z. H.: Water for food in Bangladesh: outlook to 2030, International Water Management Institute (IWMI), Colombo, Sri Lanka, IWMI Research Report 158, 32 pp., doi:10.5337/2014.213, 2014.

Chaturvedi, M. C. and Srivastava, V. K.: Induced groundwater recharge in the Ganges basin, Water Resour. Res., 15, 11561166, 1979.

CWC (Central Water Commission): Water and related statistics, available at: http://www.cwc.nic.in/main/downloads/ WaterandRelatedStatistics-2013.pdf, last access: January 2015, 2013.

Douglas, I.: Climate change, flooding and food security in south Asia, Food Security, 1, 127-136, 2009

FAO (Food and Agriculture Organization of the United Nations): Ganges-Brahmaputra-Meghna river basin, available at: http: //www.fao.org/nr/water/aquastat/basins/gbm/gbm-CP_eng.pdf, last access: January 2015, 2014.

Gleeson, T., Wada, Y., Bierkens, M. F., and van Beek, L. P.: Water balance of global aquifers revealed by groundwater footprint, Nature, 488, 197-200, 2012.
GoI (Government of India): Integrated water resources development. A plan for action, Report of the National Commission for Integrated Water Resources Development Volume I, Ministry of Water Resources, GOI, New Delhi, 1999.

GoI (Government of India): Ganges Basin, Central Water Commission, Ministry of Water Resources, New Delhi, India, availble at: http://www.india-wris.nrsc.gov.in/, last access: January 2015, 2014.

Hosterman, H. R., McCornick, P. G., Kistin, E. J., Sharma, B., and Bharati, L.: Freshwater, climate change and adaptation in the Ganges River Basin, Water Policy, 14, 67-79, 2012.

Immerzeel, W. W., Van Beek, L. P., and Bierkens, M. F.: Climate change will affect the Asian water towers, Science, 328, 13821385, 2010.

Jeuland, M., Rao, H., Escurra, J., Blackmore, D., and Sadoff, C.: Implications for climate change for water resources development in the Ganges basin, Water Policy, 15, 26-50, 2013.

Krishna Kumar, K., Patwardhan, S. K., Kulkarni, A., Kamala, K., Rao, K. K., and Jones, R., Simulated projections for summer monsoon climate over India by a high-resolution regional climate model (PRECIS), Curr. Sci. India, 101, 312-326, 2011.

Lutz, A. F., Immerzeel, W. W., Shrestha, A. B., and Bierkens, M. F. P.: Consistent increase in High Asia's runoff due to increasing glacier melt and precipitation, Nature Climate Change, 4, 587-592, 2014.

Mirza, M. M. Q.: Diversion of the Ganges water at Farakka and its effects on salinity in Bangladesh, Environ. Manage., 22, 711722, 1998

MoEF (Ministry of Environment and Forests): Status paper on River Ganga. State of environment and water quality, available at: http://www.moef.nic.in/sites/default/files/ StatusPaper-Ganga_2.pdf, last access: January 2015, 2009.

Molden, D.: Accounting for water use and productivity, International Irrigation Management Institute (IIMI), Colombo, Sri Lanka, ix, 16 pp., 1997.

Molden, D. (Ed.): Water for food, water for life: A comprehensive assessment of water management in agriculture, Earthscan, London, and International Water Management Institute, Colombo, 2007.

Muthuwatta, L., Amarasinghe, U. A., Sood, A., and Lagudu, S.: Reviving the "Ganges Water Machine": where and how much?, Hydrol. Earth Syst. Sci. Discuss., 12, 9741-9763, doi:10.5194/hessd-12-9741-2015, 2015.

NMCG (National Mission for Clean Ganga): Aims and objectives, available at: https://nmcg.nic.in/AboutGangaManthan.aspx, last access: January 2015, 2014.

Payne, A. I. and Temple, S. A.: River and floodplain fisheries in the Ganges Basin, Overseas Development Administration, Fisheries Management Science Programme, London, Final Report, R.5485, 10, 12 pp., 1996.

Revelle, R. and Lakshminarayana, V.: The Ganges water machine, Science, 188, 611-616, 1975.

Rosegrant, M. W., Cai, X., and Cline, S. A.: World Water and Food to 2025: Dealing with Scarcity, International Food Policy Research Institute (IFPRI), Washington, DC, USA, 2002.

Sadoff, C., Nagaraja, R. H., Blackmore, D., Xun, W., O’Donnell, A., Jeuland, M., and Whittington, D.: Ten fundamental questions for water resources development in the Ganges: myths and realities, Water Policy, 15, 147-164, 2013. 
Sapkota, P., Bharati, L., Gurung, P., Kaushal, N., and Smakhtin, V.: Environmentally sustainable management of water demands under changing climate conditions in the upper Ganges Basin, India, Hydrol. Process., 27, 2197-2208, 2013.

Sharma, B., Amarasinghe, U., Xueliang, C., de Condappa, D., Shah, T., Mukherji, A., and Smakhtin, V.: The Indus and the Ganges: river basins under extreme pressure, Water Int., 35, 493-521, 2010.

Sharmila, S., Joseph, S., Sahai, A. K., Abhilash, S., and Chattopadhyay, R.: Future projection of Indian summer monsoon variability under climate change scenario: An assessment from CMIP5 climate models, Global Planet. Change, 124, 62-78, 2015.
Smakhtin, V. and Anputhas, M.: An assessment of environmental flow requirements of Indian River basins, Research Report 107, International Water Management Institute (IWMI), Colombo, Sri Lanka, 36 pp., 2006.

Smith, M.: CROPWAT. A Computer Program for Irrigation Planning and Management, Food and Agriculture Organization of the United Nations, Rome, Italy, FAO Irrigation and Drainage Paper 46, 126 pp., 1992.

Vass, K. K., Mondal, S. K., Samanta, S., Suresh, V. R., and Katiha, P. K.: The environment and fishery status of the river Ganges, Aquat. Ecosyst. Health, 13, 385-394, 2010. 